\title{
A Study on Prolactin Hormone and Female Infertility in National Hospital Abuja, Nigeria.
}

\author{
${ }^{1}$ Meraiyebu Ajibola, ${ }^{2}$ Akintayo Christopher Oloruntoba,${ }^{3}$ Offiah Nneka Valeria \\ ${ }^{1,3}$ Department of Physiology, Bingham University, Karu Nasarawa State, Nigeria. \\ ${ }^{2}$ Department of Physiology, University of Ibadan, Ibadan, Nigeria.
}

\begin{abstract}
Prolactin hormone is a polypeptide involved in the differenciation of normal mammary epithelium. Prolactin hormone has 200 amino acids, and it prepares the physiology of women for lactation and maternal care. Though, it is more important for the onset rather than the maintenance of maternal care. It exhibits a circadian variation whereby it is higher in the evenings. Previous scientific reports stated that Prolactin levels are higher in nulliparous women than in parous women, due to the fact that early first full term pregnancy causes a lowering of the level of circulating prolactin hormone. Hyperprolactinemia (abnormally high levels of prolactin) is a contributing factor to both female and male infertility. Especially cases of primary infertility. This present study was carried out to investigate the frequency of the prolactin levels among the infertile female patients in National hospital Abuja, and to analyse the difference in the prolactin levels between those suffering from primary infertility and those suffering from secondary infertility. The prolactin levels among female patients suffering primary infertility and secondary infertility were studied respectively and compared to the normal range of prolactin levels in nulliparous women. The prolactin levels of patients suffering primary infertility and secondary infertility were also compared. The result of this study suggested that a prolactin hormone abnormality was not a major contributory factor to the infertility problem suffered by most Female Infertility patients in National Hospital Abuja.
\end{abstract}

Keyword: Female, Infertility, Prolactin hormone.

\section{Introduction}

Nigeria is made up of about over 250 ethnic groups with different traditions and customs, but have a similar perspective on fertility, and like most other African countries, high fertility and large families are valued in Nigeria. In most African traditions, fertility is seen as a blessing of the gods. Therefore anyone who is infertile is considered to be cursed and women tend to bear the brunt of the social stigma because their role in marriage is to give birth to children. Hence, even in modern times, they are the first to seek medical attention. The fertility transition in Nigeria as indicated in the Nigeria Fertility Survey (NFS) showed a Total Fertility Rate (TFR) of 5.94 in 1980-1982, and the 1990 Nigeria Demographic and Health Survey put the TFR at 6.01 in the period of 1988-1990. Further decline in TFR was indicated for 1992-1994 by a 1994 sentinel survey as 5.4, and for 1995-1999 by the 1999 Demographic and Health Survey as 5.2. (13). Infertility has gradually become an issue in Nigeria, but then, most people confuse infertility with sterility and sub-fertility. However, about $30 \%$ of all female infertility is caused by a hormonal imbalance of some sort. The hormones that play a major role in female fertility are follicle stimulating hormone, luteinizing hormone, estrogen, progesterone and prolactin. Prolactin is a hormone secreted by the pituitary gland. The pituitary gland is also known as the hypophysis, and is located just below the hypothalamus of the brain. Prolactin hormone is found in both men and women and is released at various times throughout the day and night. The role of prolactin is to stimulate milk production in pregnant women. It also enlarges a woman's mammary glands in order to allow her prepare for breastfeeding. It affects a woman's ovulation and menstrual cycles, which is why women who are breastfeeding rarely get pregnant. Prolactin affects the above cycles by inhibiting the two hormones necessary for ovulation: follicle stimulating hormone $(\mathrm{FSH})$ and gonadotropin releasing hormone $(\mathrm{GnRH})$ (1). High levels of prolactin (hyperprolactinaemia) is one of the major causes of female infertility. Thus, this study seeks to evaluate the relationship between the prolactin hormone and female infertility rate among Abuja out-patients in National Hospital Abuja.

\section{Materials And Method}

The Materials used for this study include: records of female patients that visited National Hospital Abuja within the past 7 years on account of infertility, including their chemical pathology Immuno Assay forms. From these records, data on the prolactin hormone levels of the infertile women, type of infertility suffered and bio data of the women were obtained. 


\section{METHODOLOGY FOR DATA COLLECTION}

A Project proposal as well as an application for Ethical Approval of the study was drawn up and presented to the National Hospital Ethical Committee. The Ethical approval was granted and a senior registrar in the Obstetrics and Gynaecology department was assigned to supervise the study.

With the assistance of the consulting physicians and the chemical pathology laboratory staff, the chemical pathology request forms of 32 randomly selected female infertility patients, were filled and their prolactin hormonal assay carried out. The data obtained from the chemical pathology request form included the following: Age, Sex, Ethnic group, Clinical summary, Last menstrual period, Usual duration of cycle, Diagnosis, Date sample was taken, Reproductive fertility hormone tests, Ovulatory serial profile, Thyroid function test, Pituitary function test, Adrenal function test, Tumour markers, Immunoglobulin test, Dynamic function tests, Results of medical lab scientist, Pathologist's report . However, the data relevant to our study from the above form were; Prolactin hormone level of the patients, the parity of the patients, the duration of the infertility problem, The type of infertility suffered by the patients.

\section{GROUPING PROTOCOL}

The 32 Patients were grouped into two based on the type of infertility they suffered; the two groups were those suffering from primary infertility and those suffering from secondary infertility. Group 1- Women suffering from Primary Infertility, while Group 2 - Women suffering from Secondary Infertility.

\section{STATISTICAL ANALYSIS}

Statistical analysis was carried out on the data obtained using the student T- test method and the results were presented in the form of tables and Bar Charts.

\section{Results}

The result obtained from the study carried out in National hospital was arranged in tables and interpreted using the T-test analytical tool. The data obtained consisted of sixteen women in each group. The women in Group one were mostly in their thirties and they had a mean prolactin level of $19.82 \mathrm{ng} / \mathrm{ml}$, which was greater than the mean of the normal prolactin level range- $15.50 \mathrm{ng} / \mathrm{ml}$. The women in group 2 were mostly in their thirties, and their mean prolactin level was $36.05 \mathrm{ng} / \mathrm{ml}$, which was also greater than the mean of the normal prolactin level range $-15.50 \mathrm{ng} / \mathrm{ml}$.

On comparison of the prolactin levels in group one and in Group two, the student t-test was used and a $\mathrm{p}$ value of ( 0.00004690) was obtained. This value indicates that the prolactin level difference between the 2 groups was insignificant. It was observed that the higher the prolactin level, the lower the duration of infertility and vice versa.

Table 1: Showing women with primary infertility

\begin{tabular}{|c|c|c|c|c|c|}
\hline & AGE(YEARS) & PARITY & $\begin{array}{l}\text { PROLACTIN LEVEL } \\
(\mathrm{ng} / \mathrm{ml})\end{array}$ & $\begin{array}{l}\text { DURATION } \\
\text { OF } \\
\text { INFERTILITY }\end{array}$ & duration in years \\
\hline 1 & 33 & $\mathrm{P}_{\mathrm{O}}^{+\mathrm{O}}$ & 17.9 & 1 YEAR & 1 \\
\hline 2 & 22 & $\mathrm{P}_{\mathrm{O}}^{+\mathrm{O}}$ & 4 & 4 YEARS & 4 \\
\hline 3 & 28 & $\mathrm{P}_{\mathrm{O}}^{+0}$ & 20.2 & 1 YEAR & 1 \\
\hline 4 & 33 & $\mathrm{P}_{\mathrm{O}}^{+1}$ & 11.93 & $\begin{array}{l}3 \text { YEARS } 6 \\
\text { MONTHS }\end{array}$ & 3.5 \\
\hline 5 & 32 & $\mathrm{P}_{\mathrm{O}}^{+\mathrm{O}}$ & 17.8 & 3 YEARS & 3 \\
\hline 6 & 36 & $\mathrm{P}_{\mathrm{O}}^{+3}$ & 17.76 & 10 YEARS & 10 \\
\hline 7 & 37 & $\mathrm{P}_{\mathrm{O}}^{+1}$ & 11.4 & 10 MONTHS & 0.8 \\
\hline 8 & 35 & $\mathrm{P}_{\mathrm{O}}^{+\mathrm{O}}$ & 14.3 & 3 YEARS & 3 \\
\hline 9 & 41 & $\mathrm{P}_{\mathrm{O}}^{+1}$ & 14.75 & 4 YEARS & 4 \\
\hline 10 & 38 & $\mathrm{P}_{\mathrm{O}}^{+\mathrm{O}}$ & 9.1 & 2 YEARS & 2 \\
\hline 11 & 46 & $\mathrm{P}_{\mathrm{O}}^{+0}$ & 26.9 & 3 YEARS & 3 \\
\hline 12 & 33 & $\mathrm{P}_{\mathrm{O}}^{+\mathrm{O}}$ & 17.9 & 1 YEAR & 1 \\
\hline 13 & 39 & $\mathrm{P}_{\mathrm{O}}^{+0}$ & 101.5 & 3 YEARS & 3 \\
\hline 14 & 38 & $\mathrm{P}_{\mathrm{O}}^{+0}$ & 9.1 & 2 YEARS & 2 \\
\hline 15 & 34 & $\mathrm{P}_{\mathrm{O}}{ }^{+0}$ & 16.4 & 1 YEAR & 1 \\
\hline 16 & 39 & $\mathrm{P}_{\mathrm{O}}^{+0}$ & 6.19 & 20 YEARS & 20 \\
\hline
\end{tabular}

Table 2: Showing women with primary infertility 


\begin{tabular}{|c|c|c|c|c|c|}
\hline & AGE(YEARS) & PARITY & $\begin{array}{l}\text { PROLACTIN } \\
\text { LEVEL } \\
(\mathrm{ng} / \mathrm{m})\end{array}$ & $\begin{array}{l}\text { DURATION } \\
\text { INFERTILITY }\end{array}$ & OF \\
\hline 1 & 23 & $\mathrm{P}_{\mathrm{O}}{ }^{+2}$ & 28.2 & 1 YEAR & \\
\hline 2 & 34 & $\mathrm{P}_{\mathrm{O}^{+2}}$ & 15.58 & 2 YEARS & \\
\hline 3 & 42 & $\mathrm{P}_{\mathrm{O}}{ }^{+1}$ & 13.8 & 11 YEARS & \\
\hline 4 & 31 & $\mathrm{Po}^{+5} \mathrm{NA}$ & 6.6 & 2 YEARS & \\
\hline 5 & 31 YEARS & $\mathrm{P}_{1}^{+1}$ & 21.5 & 7 YEARS & \\
\hline 6 & 28 & $\mathrm{P}_{\mathrm{O}^{+2}}$ & 14.5 & 7 YEARS & \\
\hline 7 & 38 & $P_{1}+2$ & 21.98 & 9 YEARS & \\
\hline 8 & 28 & $\mathrm{Po}^{-2}$ & 25.5 & 9 MONTHS & \\
\hline 9 & 42 & $P_{0}^{+3}$ & 24.7 & 1YEAR 6 MONTHS & \\
\hline 10 & 37 & $\mathrm{P}_{\mathrm{O}^{+2}}$ & 14.6 & 8 YEARS & \\
\hline 11 & 30 & $\mathrm{P}_{1}^{+1} 1 \mathrm{~A}$ & 0.43 & 2 YEARS & \\
\hline 12 & 35 & $\mathrm{P}_{\mathrm{o}}{ }^{+1}$ & 39.2 & 2 YEARS & \\
\hline 13 & 25 & $P_{1}^{+0} 1 A$ & 306 & 10 YEARS & \\
\hline 14 & 38 & $\mathrm{Po}^{+1}$ & 19.3 & 3 YEARS & \\
\hline 15 & 29 & $P_{1}^{+0} 1 A$ & 7.3 & 3 YEARS & \\
\hline 16 & 39 & $P_{1}^{+2}$ & 17.6 & 6 YEARS & \\
\hline sum & & & 576.79 & & \\
\hline
\end{tabular}

\section{Discussion}

Table 1. represents the data of women suffering from primary infertility. About twelve of the patients under this category, were in their thirties' and about twelve of the patients have never been pregnant. Altogether, there were sixteen patients under this category. The remaining four who had been pregnant previously, had not been able to carry their pregnancies up to 28 weeks (which is the age of viability in Africa), they had either suffered spontaneous abortion or voluntarily aborted their previous pregnancies. The relationship between the prolactin levels in the patients and the duration of infertility did not follow a regular pattern. However, all the patients under this category had prolactin levels that were within the normal range i.e 2 to $29 \mathrm{ng} / \mathrm{ml}$ (10) except for one patient who had a prolactin level of $101.5 \mathrm{ng} / \mathrm{ml}$ which is rather high for a non-pregnant woman. The patient with the longest duration of infertility (20years), had a prolactin level of $6.19 \mathrm{ng} / \mathrm{ml}$, which is at the lower limit of normal. The standard deviation was calculated and the mean value of the prolactin levels in the patients under this category was obtained. The mean value obtained was $19.82 \mathrm{ng} / \mathrm{ml}$, and it is higher than the mean value of the normal range which is $15.50 \mathrm{ng} / \mathrm{ml}$. Hence, these values correlate with the fact that raised prolactin level is associated with primary infertility. However, it was observed that there were high prolactin level, this pattern does not correlate with the fact that high levels of prolactin (hyperprolactinemia) is a significant cause of primary infertility because it affects both ovulation and the implantation of the embryo in the uterus(28). However, the fact that the women under this category married at different ages may have contributed to the pattern observed. Also, other factors other than prolactin levels may have contributed to the infertility suffered by these patients. Table 2. represents the data of female patients suffering secondary infertility. Nine of these patients were in their thirties, five in their twenties and two in their forties. All 16 of the patients had achieved pregnancy previously, though ten of them had either suffered miscarriages or been delivered of stillbirths. Six of them however, were successfully delivered of at least one pregnancy amidst miscarriages and stillbirths. The prolactin level in this category of patients, is mostly within the normal range except for two of them that were higher than normal $(39.2 \mathrm{ng} / \mathrm{ml}$ and $306 \mathrm{ng} / \mathrm{ml})$, and one of them that was lower than normal $(0.43 \mathrm{ng} / \mathrm{ml})$. The longest duration of infertility under this category is 11 years. The relationship between the prolactin level and duration of infertility did not follow a regular pattern. The standard deviation for the prolactin levels of the women under the category secondary infertility was calculated and the mean also obtained (table 2). The mean value obtained $(36.05 \mathrm{ng} / \mathrm{ml})$ was very much higher than the mean value of the normal range $(15.50 \mathrm{ng} / \mathrm{ml})$. This however, does not correlate with the fact that prolactin levels in parous women is significantly lower than prolactin levels in nulliparous women (1). From the study carried out, a comparison of the effect of prolactin levels in the two categories of patients that is, primary infertility and secondary infertility, was carried out. The $p$ value obtained from the student $\mathrm{t}$-test $(\mathrm{p}<0.01)$, indicated that there was a significant difference in the prolactin levels between the women in group one and group two because the $p$ value was less than 0.05 . This significance does not correspond with the previous study that indicated that prolactin levels in parous women are significantly lower than prolactin levels in nulliparous women (3).

\section{Conclusion}

From the study carried out, it can be concluded that prolactin level abnormality was not the major cause of primary infertility, and that it was also not the major cause of secondary infertility among the infertile female patients in National hospital Abuja. 


\section{References}

[1] Bernstein Leslie, Pike M.C., Ross R.K., Judd H.L., Brown J.B., Henderson B.E.,(2012). Estrogen and sex hormone-binding Globulin levels in Nulliparous and parous women. Oxford journals. Journal of the National cancer Institute. 74: 741-745.

[2] Boland R. (2010): Second trimester abortion laws globally actuality, trends and recommendations: Journal of Reproductive matters:18: pp $67-89$.

[3] Bridges R.S. and Byrnes E.M. 2006. Reproduction-Development. Endocrinology,Bridges and Byrnes. 147(5): 2575Coomaraswamy R. (1994): violence against women, its causes and consequences:Journal of commission on Human Rights resolution:45: $\mathrm{p} 92$.

[4] Donnica M. (2006): Women's Health for life: what is secondary infertility (online). Available from http://www.DrDonnica.com (Accessed $5^{\text {th }}$ February, 2011).

[5] Doorkenoo and Efua (1994): Female genital mutation: The practise and itsprevention. London, minority Rights publication. Pg 196

[6] Ekwere P.D., Archibong E.I., Bassey E.E., Ekabua J. E., Ekanem E.I. and Wasobo P.F. (2007): infertility among Nigerian couples as seen in Calarba: Port Harcourt Medical Journal:2: p 35.

[7] Fahmy A., Mouelhy M. T., Ragab A. R (2010): Female genital mutation/cutting and issues of sexuality in Egypt: Journal of reproductive Health matters: 18 : pp181 -190 .

[8] Female Infertility (2010): causes of female infertility Health Grades Inc. available from http://www.wrongdiagnosis.com (Accessed $25^{\text {th }}$ January, 2011).

[9] Faupel-Badger Jm, Shenman ME, Closas G.M., Gaudet M.M., Falk R.T., Andaya A., Pfeiffer R.M., Yang X.R., Lissowska J., Brinton L.A., Peplonska B., VonderhaarB.k. and Figueora J.D. 2010. 11.Prolatin serum levels and breast cancer. British journal of cancer 103(67): 1097-1102.

[10] Female Infertility (2010): diagnosis of female infertility.HealthGrades Inc (online). Available from http://www.wrongdiagnosis.com (Accessed: $7^{\text {th }}$ February, 2011).

[11] Feyisetam B. and Akinrinola B. (2000): Fertility Transition in Nigeria: Trends and Propects, google books (online). Available from google.com.ng (Accessed $26^{\text {th }}$ September, 2011).

[12] Health Encyclopaedia (2010): Diseases and conditions: Treatment of female fertility, The health central network, Inc. (online). Available from http://www.healthscout.com (Accessed 12 $2^{\text {th }}$ February, 2011).

[13] Galan N. (2011). About.com Health's Disease and Condition: what is prolactin? (online). Available from http://www.about.com (Accessed 20 $0^{\text {th }}$ October, 2011).

[14] Hosken F.P (1994, Lexington): The Hosken report: genital and sexual mutation of females, $4^{\text {th }}$ revised edition, Lexington. Women's international Network news. Pg 444.

[15] Hostile Cervical Mucus (2010): Hostile cervical mucus and infertility. Einstein Industries, Inc. (online). Available from http://www.docshop.com (Accessed $11^{\text {th }}$ February, 2011).

[16] Infertility (2005): what causes infertility in women (online) Available from http://www.health-cares.net (Accessed $15^{\text {th }}$ February, 2011).

[17] Kasonde J. M. (2008); Reproductive health in developing countries, Geneva foundation for Medical Education and Research. Available from http://www.gfmer.ch/Endo/Lectures (Accessed 25th January, 2011).

[18] Lamana M.A. Riedmann A. C. and Riedmann A: Marriages and families, google books (online). Available from http://www.cengagebrain.com (Accessed $10^{\text {th }}$ February, 2011).

[19] Larsen U. (1995): Trends in infertility in Cameroon and Nigeria journal of international family planning perspective: 21 : pp $139-140$.

[20] Leke R.J, Oduma J. A, Bassol M.S, Basch AM and Grigor KM (1993) Regional and geographical variations in fertility: Effects of environmental, cultural and socioeconomic factors, pubMed (online) available from http://www.ncbi.n/m.nih.gov/pubmed.

[21] Mama's Health online (2012). Pregnancy and osteoporosis: lactation and bone loss. Available from http://www.mamashealth.com (accessed $27^{\text {th }}$ July, 2012).

[22] MasoudMoslehi and MajidAssadi 2012. Bilateral radio iodine uptake by the non-lactating breast of a single nulliparous woman. $\begin{array}{ll}\text { Archives of medical science 8(3): 575-577 } & \end{array}$

[23] M.c. Yu, V.R. Gerkins, B.E. Henderson, J.B. Brown and M.C. Pike. 1984. Elevated levels of prolactine in nulliparous women. British Journal of cancer. 43(6): 826-831.

[24] Moss C. (2008): Infertility African Women branded witches, First Active media Ltd (online), Available From http://www.cazfemale.first.html (Accessed $30^{\text {th }} \mathrm{Jan}$. 2011)

[25] Obono O. (2001): Life Histories of Infertile women in ugep, Southern Nigeria:Journal of African population studies: 19: pp 69 71.

[26] Rosenthal M. (2011). Books on infertility: Testing for a hormonal problem (online). Available from http://www.cushingshelp.com (Accessed 20 $0^{\text {th }}$ October, 2011).

[27] Schradin Carsten and Anzenberger Gustl (2012), Prolactin, the hormone of paternity. Journals of the American Physiological Society 14(6): 223-231

[28] Shah I. and Ahman E. (2010): unsafe abortion in 2008; global and regional levels andtrends: Journal of Reproductive Health matters 18: pp $90-101$.

[29] Shriver E. (2006). Health Information/Fertility (online). Available from http://www.nichd.nih.gov (Accessed30 ${ }^{\text {th }}$ September, 2011)

[30] Su Xuefen, Hankinson S.E., Clevenger C.V., Eliassen H.A., Tworoger S.S., (2009). Energy balance, early life body size and plasma prolactin level in postmenopausal women. Cancer causes control. 20(2): 253-262

[31] Tiana C. (2010): Female Health: Infertility in women (online). Available from http://www.nigerianbestforum.com (Accessed ${ }^{\text {th }}$ October, 2011)

[32] Available from http://www.docshop.com (Accessed $12^{\text {th }}$ February, 2011). What causes female infertility: causes of failure to Ovulate: available from http://www.stanford.edu (Accessed $20^{\text {th }}$ January, 2011).

[33] Zuraida A.S. (2010): Psychological distress among infertile women, exploring Biopsychosocial Response to infertility: Journal of MJP online early. 